\title{
АКТУАЛЬНЫЕ ПРОБЛЕМЫ ГОСУДАРСТВА И ПРАВА В ДОКУМЕНТАХ ХVII ВСЕМИРНОГО РУССКОГО НАРОДНОГО СОБОРА
}

\section{2} декабря исполняется двадцать лет со дня принятия Конституции Российской Федерации. В российском обществе обозначилось два противоположных подхода в оценке итогов развития страны. Первый подход, Российское правоведение, сложившееся после событий 1993 года, активно способствовало формированию колониально-сырьевой модели российской экономики и имитационной модели функционирования политической системы, не заметило утраты суверенитета и введения внешнего управления (Е.Федоров, Т.Хабарова). Второй подход характерен для либерального фундаментализма и составляет теоретическую основу Конституции Российской Федерации.

Выступление В. Путина на Валдайском форуме (сентябрь 2013 года) обозначило необходимость смены политико-правового дискурса - переход от либерально-западного (механически-скопированного) обществоведения и правоведения к национальному. Эти идеи были развиты в документах XVII Всемирного Русского Народного Собора. Рассмотрению указанных проблем посвящен настоящий доклад.

1. Причины системного кризиса: 1) Формирование криминально-олигархической модели сырьевой экономики. Экономические потери вследствие шоковой терапии в 90-е годы сравнимы с потерями периодов Гражданской войны и гитлеровского нашествия. Этот ущерб складывается из разорения предприятий криминальной приватизацией, вывоза капитала, утраты возможностей воспроизводства основного капитала из-за прекращения долгосрочного кредита. Этот ущерб продолжает увеличиваться под воздействием механизмов неэквивалентного внешнеэкономическо- го обмена, поддерживаемого политикой накопления валютных резервов за рубежом под символический процент в обмен на привлечение гораздо более дорогих зарубежных кредитов. Этот ущерб дополняется утратой национального контроля над крупной промышленностью, выведенной из-под российской юрисдикции в оффшоры, что делает невозможным самостоятельное развитие российской экономики и ставит под угрозу суверенитет страны .

2) Функционирование имитационной политической системы. Современная демократия - это декорация, позволяющая полностью изъять население из политики, то есть из процесса принятия стратегических решений. Потому что стратегические решения в этой системе - это решения об управлении финансовыми потоками. Однако маленькая проблема: центр управления этими потоками находится точно не у нас.

3) Наличие мародерской по происхождению элиты. Все три русские катастрофы (1612, 1917 и 1991 годов), когда наше государство аннигилировалось, имеют одну общую составляющую. Это предательство элит. Историческая особенность российских элит: принадлежность к элите не сопровождается лояльностью к собственной стране и собственному народу. Скорее наоборот.

Исторически российская власть не идентична элитам. И только этим обеспечивается её легитимность. Она абсолютна, в том смысле, что не делится с элитами властью. В моменты кризиса и слабости, когда элиты завладевают властью - то есть возникает в том или ином историческом контексте та самая либеральная модель, - эта модель и эта власть оказываются нелегитимны с точки зрения общества. И начинается уничтожение элит, высших классов низшими. При 
этом предательство на то и предательство: элиты всегда обращаются к внешнему врагу для защиты от своего народа и своего государства.

Вопрос, способны ли нынешние элиты на такое в момент кризиса, когда им представится возможность взять власть и реализовать либеральную модель, вопрос смешной. Для нынешних российских элит, по происхождению мародёрских, давно разместивших свои активы, недвижимость, потомство и политическую лояльность за рубежом, вообще никакого такого риска не существует (кроме как если случайно отловят и замочат). Если не получится, они могут вернуться сюда, как уже настоящие полноценные коллаборационисты и полицаи под защитой оккупационной администрации.

4) Отсутствие национальной идеи и господство квазиидеологии (наша посткатастрофная элита - «полуолигархия», имеет свою идеологию. Как и положено, прикрытую утопией - «всеобщей представительной демократией». Эту тоталитарную идеологию можно назвать компрадорским олигархическим либерастизмом (политкорректное название - либеральный фундаментализм.

Праволиберальный блок управления страной оправдывает начинающуюся рецессию мировым кризисом, игнорируя успехи ведущих развивающихся стран, в том числе входящих в БРИКС.

Бесконечно повторяя известные догмы рыночного фундаментализма, давно опровергнутого управления в теории и на практике экономического развития, он (праволиберальный блок управления страной) пытаются гипнотизировать власть, маниакально призывая в очередной раз наступить на грабли, об которые российская экономика неоднократно расшибала себе лоб, в 1992, 1994, 1998 и 2008 годах) $)^{1}$.

2. Критика политико-правовой доктрины Конституции Российской Федерации 1993 года в работе «Национальная идея». Конституция РФ, содержит характеристики государства как демократического, социального, правового, федеративного. Фактически же российское государство, как отмечается в юридической литературе, не является демократическим, развитым социальным государством, не является полностью правовым, Россия - федерация. Однако ее федеративная организация существует в ассиметричной форме ${ }^{2}$.

1 Леонтьев М. Идеология суверенитета // Однако август сентябрь 2013 (169), с. 10-12.

2 Чиркин В.Э. Конституция : российская модель. - М.:
В действующей Конституции РФ, определены высшие ценности - это права и свободы человека и гражданина. Нравственность, справедливость, даже само существование России к высшим ценностям не отнесены. Такой методологический подход связан, по мнению авторов шеститомной монографии «Национальная идея России», с неолиберальной космополитической доктриной, навязанной стране сразу после гражданского конфликта 1993 г., после выстрелов танков по «Белому дому». Определенную примиряющую роль в тот период сыграло принятие Конституции РФ ${ }^{3}$.

Но спустя 20 лет, т. е. после очень длительного периода времени для исторических экспериментов, перед лицом надвигающихся новых угроз для существования российской государственности пришло время переосмыслить важные обстоятельства и реалии обустройства жизни страны.

Критическое осмысление политико-правовой доктрины Конституции 1993 года может быть сведено к следующим положениям:

1) Никаких иных значимых ценностей, кроме прав и свобод человека и гражданина, в Конституции РФ нет. Права и свободы при этом не увязываются с обязанностями и ответственностью. Государству же не предписано никакой ответственности, а также обязанностей, за исключением признания и соблюдения прав и свобод человека и гражданина.

2) У страны не определены цели и ценностей развития. В какую сторону она движется и куда должна прийти? Что должно объединять народ и подвигать его на свершения? Ответов в Конституции нет.

3) Неолиберальная риторика, в поле которой построена Конституция РФ 1993 г., указывает только на «конкурентоспособность страны». Как будто страна - это коммерческая организация, которая на каких-то рынках с кем-то конкурирует.

4) Конституция РФ запретила идеологию страны. А идеология включает в себя ценности, избранные обществом. Общество и страна без ценностей? Разве может такая страна быть успешной?

5) Конституция РФ игнорирует цивилизационную специфику русской (российской) цивилизации. Она прямо отрицает российскую государственность времен Советского Союза. Слово «русский» в ней употреблено только один раз (и только по отношению к

Юристъ, 2004.,с.44-46., его же Государственное управление. Элементарный курс, - М.: Юристь, 2002.,с.36.

3 Национальная идея России. Т. 6.С.4021-4025. - M,: Научный эксперт, 2012. 
языку). Но каждая цивилизация успешна только тогда, когда она настроена на свой собственный уникальный рецепт успеха. Чужие рецепты тут беспомощны и даже вредны. Русского народа по Конституции РФ вообще не существует. Государственных (!) языков, помимо русского, в ней установлено множество ( Имеются в виду государственные языки республик - субъектов РФ (статья 68 Конституции РФ).

6) Конституция РФ нацелена на единственный безусловный интерес - богатого меньшинства, поэтому имеют место безудержная приватизация, вывоз капиталов из страны, сырьевизация и архаизация экономики, фальсификация продуктов питания и лекарств, коммерциализация социальной и гуманитарной сфер.

7) Интерес частного (и прежде всего иностранного) капитала торжествует над национальными интересами страны и ее народа. Все: от образования и здравоохранения до деятельности Центрального банка РФ, устраивается на коммерческий лад, идет на продажу, начиная с земли и активов и заканчивая «услугами государства» и ставкой рефинансирования.

8) Государство превращается в сервисное (т. е. предоставляющее услуги за плату), а не жизнеобустраивающее.

9) Многое из того, что сегодня делает страну неуспешной, запрограммировано в Конституции РФ 1993 г. Чтобы конституция не обслуживала интересы только богатого меньшинства и иностранных государств, а служила собственной стране и ее народу, она должна быть сориентирована на успех страны и ее народа.

Методологический подход к проектированию научного макета новой Конституции России. «Модель страны», «успешность страны», по мнению авторов шеститомной монографии «Национальная идея России», вводятся как базовые категории в научно формализованном пространстве функций цели и множества независимых параметров государственного управления, управленческого выбора4.

Это требование порождает специальный алгоритм построения конституции, который гарантирует, что она будет работать во имя поставленных перед ней целей. Алгоритм шеститомной монографии «Национальная идея России» в разработан на основании логико-философской и математической теорий успешности сложной социальной системы.

В статье установлена связь Основного закона (Конституции) России, программирующего развитие страны, с реальными ее достижениями и вызовами. По

4 Национальная идея России. Т. 6. - М,: Научный эксперт, 2012. ,c.4021-4025. результатам исследования предложены научный макет новой Конституции России, Доктрина безопасности и развития России и производная от этих базовых документов система нормативно-правовых актов, институциональных, социально-экономических, региональных, финансовых, внешнеполитических и гуманитарных принципов жизнеустройства России.

У государства в широком смысле, по мнению авторов шеститомной монографии Национальная идея России, есть неотъемлемые функции или миссия. Это безопасность и устойчивость развития, включая демографическое, мировоззренческая осмысленность жизни и уровень благосостояния ее населения, народосбережение, занятость, здоровье, психологический комфорт, уверенность в будущем. И эти функции далеки от установок государства «сервисного типа».

Конституционно-правовые основы жизненно важных параметров развития страны. Государство управляет десятками жизненно важных параметров развития. По мнению авторов шеститомной монографии «Национальная идея России», оно выбирает их прогнозирует их и управляет ими в количественном, полуколичественном и качественном виде $\mathrm{e}^{5}$.

Радикализация конституционной неолиберальной космополитической доктрины в последнее время явно ориентирует страну на движение к кризису и, возможно, распаду. Происходит это потому, что государственно-управленческая стратегия исходит из ошибочных посылок, несовместимых с факторами успеха страны.

Таких количественных примеров очень много. Таким параметром (количественным) является, например, коэффициент монетизации экономики. Результаты управления этим параметром - изъятие из экономики России около 3 трлн. долл. денежных средств.

Доля государственной собственности в структуре всей собственности страны уже ниже, чем в странах с рыночной экономикой.

Доля оплаты труда в ВВП страны занижена в 2-2,5 раза. Доля госрасходов в ВВП страны ниже, чем в США.

Доля инвестиций в ВВП в России в 2,5 раза ниже, чем в Китае. Прогрессия подоходного налога в России вообще отсутствует.

Отношение экспорта к импорту в России в 2-3 раза больше, чем необходимо по балансу материальных трансграничных переносов, что противоречит национальным интересам.

Государство устанавливает полуколичественные параметры развития (например, степень политиче-

5 Национальная идея России. Т. 6 . - М,: Научный эксперт, 2012. C4026-4031. 
ской свободы, которая в России характеризуется наличием партийных суррогатов, криминализованных лоббистских структур, отсутствием активно действующих профсоюзов), которые влияют на эффективность государственной власти. Степень реальной независимости СМИ также зависит от воли государства. В России они либо подчинены административному контролю, либо приватизированы и служат узкокорпоративным интересам, но принципиально не контролируются с точки зрения защиты нравственности населения страны.

Государство устанавливает качественные порядки, например, охраняя или нет (как в современной России) нравственность. То есть вводя или не вводя запреты на распространение в СМИ порнографии, сцен насилия и жестокости, асоциального поведения, управляя Интернетом или принципиально от этого самоустраняясь (85\% ресурсов в Интернете - безнравственны и просто криминальны с точки зрения незаконных и деструктивных призывов).

Bce, что перечислено (а это лишь малая часть), и есть потенциалы (или

факторы-потенциалы) развития страны. Общество и государство могут управлять ими. Но каким именно образом - это вытекает из сделанного ими выбора. А делают выбор они, исходя из Основного закона страны и всего вытекающего из него законодательства. Таким образом, становится понятна взаимосвязь конституции страны и успеха ее развития. Конституция программирует развитие страны.

Факторы-потенциалы описывают основные системы страны, ее ценностный выбор, который формирует мировоззрение и мотивирует поведение и деятельность общества от внутрисемейных отношений до трудовых и ратных. Они описывают институты образования, воспитания, науки, здравоохранения, культуры, обороны, средств массовой коммуникации и др.

В шеститомной монографии «Национальная идея России» авторами разработан научный макет новой Конституции и доктрина безопасности и развития России и реализован специальный институт «высших ценностей России», из которого вытекает все построение государства и его жизнеустройство ${ }^{6}$.

\section{3. Состояние методологии изучения государства и} права. Наиболее влиятельным крылом российского правоведения после событий 1993 года стал нормативизм (неопозитивизм), или «чистая» теория права Г. Кельзена. Для политико-правовой доктрины, поли-

6 Национальная идея России. Т. 6, глава 19. - М,: Научный эксперт, 2012., с.4021 - 4030. тического режима 1993 года это означает, во-первых, формальное закрепление в Конституции - (статья 13) исключения идеологических и аксиологических (ценностных) аспектов.

Противопоставляя науку идеологии, современная российская политико - правовая доктрина, полагает, что теория права должна быть свободной по отношению к любой идеологии, только в этом случае она может быть наукой в современном смысле слова. Однако подобный “ нейтрализм» не выдерживает проверки и оказывается мнимым. «Деидеологизированная» юриспруденция на самом деле оказывается одним из вариантов оправдания существующего положения вещей.

Во-вторых, «чистота» рассматриваемой теории предполагает ограничение ее сферой формально-логических построений, изъятия из нее любых социологических аспектов, т.е. попыток рассмотреть право во взаимосвязи с другими явлению общественной жизни. Философско -методологической основой такого подхода является субъективный идеализм. Данный подход, крайне обедняя юридическую науку, ставит жесткую задачу объяснить право само из себя, как самодавлеющую систему (переименование курсов теорию права и государства), в отрыве от социального бытия.

В угоду конъюнктуре, начисто отказавшись от одной, и тут же «восприняв» другую, новую идеологию авторы, участники такого рода экспериментов, сами порой того не ведая, загнали себя и страну в тупик. Развитие государственно-правовой теории и методологии в подобных случаях подменяется, как правило, самым заурядным подражательством не всегда лучшим образцам цивилизованного Запада, чистым эмпиризмом в сочетании с переложением общеизвестного материала, неподдельным самобичеванием и неподражаемым в адрес бывшего СССР и других ранее называвших себя социалистическими, стран критицизмом ${ }^{7}$.

В исследованиях проблем государства правовая тематика явно превалирует над государствоведческой. Поэтому, даже когда исследователи обращаются к проблемам правового государства, «на первое место выходят проблемы правопонимания, а вопросами государствопонимания и государствоведения, по существу, никто и не занимается... $\Perp^{8}$.

7 Методологические проблемы правоведения / Под. ред. М.Н. Марченко. - М.: Изд.-во МГУ, 1994.с.3.

8 Раянов Ф.М. Матрица правового государства и наша 
Отсюда стремление к формально-правовому описанию национальной государственной реальности в соответствии с универсальными, типизированными представлениями о сущности и значении государства. Это нередко выхолащивает специфические закономерности и тенденции развития и трансформации российской государственной власти, публичного управления, либо приводит к редукционизму - упрощенному пониманию проблем отечественного государствоведения ${ }^{9}$.

Особенности этой либеральной идеологии показал академик РАН Гринберг Р.С.: «Если коротко, речь идет о нашей неизбывной страсти внедрять якобы прогрессивные в данный момент концепции в родном Отечестве. На этот раз мы стали жертвой рыночного фундаментализма или концепции неолиберальной экономики, которой нас усиленно «потчевал» Запад и которая давно отвергнута всеми развитыми странами в качестве основы для развития экономики. Российских реформаторов Запад настойчиво уговаривал, потому что хотел испытать «в деле» эту концепцию, ставшую популярной в конце 1970-х годов на фоне тогдашней стагфляции и энергетического кризиса» ${ }^{10}$.

4. Новый духовно-теоретический дискурс в материалах XVII Всемирный Русский Народный Собор. XVII Всемирный Русский Народный Собор прошел 31 октября - 6 ноября 2013 года в г. Москве. Собор рассмотрел тему «Россия как страна-цивилизация. Солидарное общество и будущее российского народа». Собор обратился к согражданам и соотечественникам с Cоборным словом.

Соборное слово содержит новый духовно-теоретический дискурс развития общества не совпадающим с либерально -западным подходом Конституции 1993 года.

Остановимся на идеях провозглашенных XVII Bceмирным Русским Народным Собором:

1. Нашей целью как считает Собор, является общество, в основе которого - согласие большинства о фундаментальных ценностях, лежащих в основе человеческого бытия. На XV Всемирном Русском Народ-

юридическая наука //Государство и право, 2006, № 8, с. 45. 2010’03 ВЛАСТЬ 45

9 Чиркин В.Е. Государствоведение : учеб.для магистрантов по направлению «Юриспруденция» - 3-е изд.,испр. и доп.- М.: Воронеж, 2012.

10 Гринберг Р.С. Ловля попутного ветра// Российская газета 17 февраля 2010. № 33. ном Соборе было во всеуслышание сказано, о каких ценностях идет речь. Это вера, справедливость, мир, свобода, единство, нравственность, достоинство, честность, патриотизм, милосердие, семья, культура и национальные традиции, благо человека, трудолюбие, самоограничение, жертвенность.

Эти ценности имеют вечное, непреходящее значение. Мы считаем тупиковыми призывы объявить ценности чем-то относительным, служебным, лишенным смысла вне пределов сознания отдельных индивидуумов и договоренностей между ними. Без истинных ценностей и идеалов общество будет духовно оскоплено, лишено творческого заряда, перспективы, и, в конечном счете, будущего.

Консолидированное вокруг базовых ценностей моральное большинство имеет полное право создавать на их основе собственную социальную модель, невзирая на окрики агрессивного меньшинства, отрицающего идеалы и ценности, следующего исключительно собственной интеллектуальной и духовной гордыне.

В основе этой социальной модели должен лежать ответ на вызовы неравенства и социальной несправедливости, демонстрирующий нашу способность преодолеть их на путях реализации идеи социального государства и повышения жизненного уровня населения.

Разнообразие и культурное богатство человечества определяется сосуществованием ряда самостоятельных обществ-цивилизаций. Каждое из них имеет свои творческие начала, проявляет собственные закономерности в развитии, вносит неповторимый вклад в сокровищницу мировых достижений.

Ценности, которые определили нашу модель общественного развития, не единожды были востребованы в глобальном масштабе, определяя ход мировой истории в ее решающие моменты. Эти ценности будут востребованы и впредь.

Так, наша цивилизация воплотила модель равноправных, справедливых межнациональных отношений, отвергнув доктрину «народов-господ» и «народов-рабов». Россия сыграла решающую роль в разгроме гитлеризма, в сокрушении мировой колониальной системы. Сегодня принцип равноправия народов и культур, являющийся базовой ценностью Российской цивилизации, является общепризнанным на планете. И мы обязаны не только хранить память о наших великих победах, но быть их достойными наследниками. Ныне именно Россия является главным гарантом многополярного мира, сдерживая амбиции тех, кто претендует на глобальное доминирование.

Будучи динамичным, максимально открытым для технического и социального прогресса обществом, Рос- 
сийская цивилизация проявила беспримерную стойкость в отстаивании своих идеалов. Сегодня именно Россия имеет все основания быть всемирным оплотом традиционных семейных ценностей, не смирившись с агрессивной проповедью аморализма и легализацией все более широкого круга греховных деяний.

2. Общественным идеалом Российской цивилизации является солидарное общество ${ }^{11}$, в основе которого лежат не конфликт и конкуренция, а взаимопомощь и сотрудничество всех его членов, разных социальных, этнических, религиозных и политических групп. Стремление к солидарному обществу пронизывает историю России, находя отражение в принципах соборности, в симфонии государства и Церкви, в опыте общины, прихода, артели, казачьего круга, совета, коммуны. Для нашей цивилизации не характерен выраженный конфликт между народом и властью, наукой и религией. Наше общество всегда стремилось преодолеть раскол по партийному признаку.

Ценности солидарного общества становятся актуальными в современном мире, который по мере роста материального могущества людей стал слишком тесным для общества перманентного конфликта. Непрерывная экономическая гонка и постоянная борьба за ресурсы толкают человечество от одного военного конфликта к другому, что в итоге может завершиться столкновением цивилизаций.

11 Понятие солидарное общество. Само название происходит от латинского слова «solidas», что значит - твердый, надежный, крепкий. Для того, чтобы быть крепким, надежным, такое общество должно быть сцепленным, хорошо собранным. Латинское название соответствует русскому слову соборность, т.е. совместность, сцепленность. «Цельность»-это тоже синоним, связанный с русскими философами славянофилами, которые призывали к соборности, цельности.

Чему противостоит солидарное общество? Солидарное общество противостоит обществу разрозненному, разделенному, распыленному, дискретному, обществу, в котором каждый индивидуум действует по своей собственной логике.

Понятию солидарного общества противостоит общество разрозненное, индивидуалистическое, где отдельные индивидуумы двигаются по своей собственной индивидуальной траектории, не обращая внимания на целое, это общество, разделившееся на части. Вот два понятия. Каковым же является наше общество? Существует идеология, направленная на формальное опровержение понятия солидарного общества. Эта идеология утверждает, что ценность индивидуума превыше всего, предполагает, что только индивидуализм, забота о себе, создание личной карьеры, обрывание всех социальных связей являются путем к благополучию. Эта политическая идеология называется либерализм. Эта идеология настаивает на том, что солидарное общество-это плохое общество, его не нужно строить, о нем не нужно говорить, а нужно строить либеральное общество.
В этих условиях создание солидарного общества это задача, которую ставят перед нами народ и сама жизнь. Творческие усилия российского интеллектуального класса, нашей гуманитарной и административной элиты должны быть направлены на поиск социальных, экономических, политических механизмов, которые позволят развиваться в сторону общественной солидарности, исключающей как перманентный конфликт, так и принудительное подавление индивидуальной активности.

3. Ключевой предпосылкой движения к солидарному обществу является диалог между основными этнокультурными группами. Будучи на протяжении 20 лет общественной трибуной русского народа, объединяя на основе общенациональных базовых ценностей людей разных профессий, культурных предпочтений и политических взглядов, Собор готов стать инициатором подобного диалога, и, в соответствии со своими уставными целями и задачами, выступить в нем от лица русских. Сам факт организации подобного диалога с однозначным признанием этнокультурной субъектности русского народа в межнациональном пространстве современной России послужит снижению межнациональной напряженности.

Важнейшей темой межнационального диалога должны стать поиски цивилизационной формулы российской идентичности, разделяемой большинством граждан России независимо от их национальности и вероисповедания. Залогом успеха подобной дискуссии является солидарная позиция традиционных религиозных общин России - православных, мусульман, буддистов, иудеев, констатирующих созвучие и близость их представлений о нравственности и аморальности, о добре и зле.

Концепция России как уникальной страны-цивилизации, ощущение принадлежности всех ее жителей к единой и уникальной цивилизационной общности должна сыграть решающую роль в процессе формирования полиэтнической российской нации. Собор призывает представителей власти, научного сообщества, деловых кругов, средств массовой информации приложить все усилия для широкого и массового распространения идей российской цивилизационной идентичности в нашем народе.

Одной из ключевых предпосылок межнационального мира и согласия в стране является полноценная реализация права ее народов на этнокультурное развитие. Государствообразующий русский народ, к которому принадлежит четыре пятых населения России, ни в коем случае не должен стать исключением из этого правила. Необходимо создание современ- 
ной, на уровне стандартов XXI века, инфраструктуры его этнокультурного развития. Всемирный Русский Народный Собор предлагает в кратчайшие сроки на государственном уровне решить вопрос о реализации программы строительства многофункциональных русских культурных центров, призванных в том числе стать центрами социальных и межэтнических контактов, способствующих адаптации мигрантов в российское общество.

4. Опыт Югославии и бывшего СССР, где потерпели крах попытки реализовать на практике этнополитические утопии «единой югославской нации» и «новой исторической общности - советского народа» должен стать грозным предостережением для тех, кто под предлогом достижения межнационального согласия стремится к подавлению национальной идентичности русских, настойчивым попытках растворить их в некоей искусственно сформированной «новой» нации, ослаблению единства русского народа, его искусственному разделению на региональные субэтносы, изъятию самого слова "русский» из официальных документов, научных докладов, образовательных программ.

Национальная политика, проводимая в России, должна носить реалистичный характер, а не находиться в зависимости от утопических построений. Цепь столкновений на этнической почве, произошедших в последние годы, показывает, что центр противоречий в современной России перемещается в межнациональную сферу. Разрешение существующих в этой области противоречий становится ключевым для будущего страны.
Обманчивой дилемме этнической сегрегации или ассимиляции народов в едином «плавильном котле» нужно противопоставить опыт сохранения этнокультурного разнообразия, опыт сосуществования этносов, объединенных общими цивилизационными ценностями. Говоря словами великого мыслителя Ивана Ильина, Россия «сколько языков получила, столько и соблюла». Сегодня актуальной остается задача сбережения национальной субъектности всех народов нашей страны, и прежде всего русского народа.

Упадок русского национального самосознания будет иметь катастрофические последствия, в историческом плане сравнимые с крахом Римской империи и гибелью Византии: это будет конец России как государства и как особого культурно-исторического мира. Всемерное же укрепление национального самосознания русских, сбережение этнокультурной идентичности всех народов России, формирование многонациональной цивилизационной общности - это триединая задача отечественной национальной политики.

Вместо заключения. Всемирный Русский Народный Собор со всей ответственностью заявляет, что только на путях реализации продекларированных устремлений возможно преодоление межнациональной розни, социального неравенства, психологической и информационной зависимости от иностранного влияния. Только в этом случае Россия сможет достойно ответить на стоящие перед ней цивилизационные вызовы и продолжить свой исторический путь в третьем тысячелетии. Данные устремления являются теоретической и духовно-нравственными основами возрождающегося национального правоведения России.

\section{Библиография}

1. Государственное управление. Элементарный курс. - М., 2002.

2. Куракин А.В. Предмет административно-правового регулирования в механизме противодействия коррупции. - Домодедово, 2013. - С. 12.

3. К Куракин А.В., Костенников М.В. Актуальные проблемы административного права. - М., 2013.

4. Леонтьев М. Идеология суверенитета // Однако август-сентябрь 2013 (169).

5. Национальная идея России. Т.

6. - М., 2012. 6. Раянов Ф.М. Матрица правового государства и наша юридическая наука // Государство и право. 2006. № 8 .

7. Чиркин В.Е. Конституция: российская модель. - М., 2004.

8. Чиркин В.Е. Государствоведение. - М., 2012.

9. Костенников М.В. К вопросу о некоторых актуальных проблемах административного права // NB: Административное право и практика администрирования. - 2013. - 4. - С. 71 - 95. URL: http://www.e-notabene.ru/al/ article_8840.html

10. Гуляихин В.Н. Правовой менталитет российских граждан // NB: Вопросы права и политики. - 2012. - 4. - C. 108 - 133. DOI: 10.7256/2305-9699.2012.4.310. URL: http://www.e-notabene.ru//r/article_310.html

11. Ю.А. Тихомиров, Г.А. Василевич Государственное управление и перспективы развития // Журнал зарубежного законодательства и сравнительного правоведения. - 2011. - 6. - С. 21 - 25. 
12. Н. М. Добрынин Размышления о проблемах становления правового государства в России. // Право и политика. - 2012. - 2. - С. 232 - 242.

13. Купреев С.С. Тенденции развития государственного управления в России в 2008-2009 годах // Административное и муниципальное право. - 2010. - 2. - С. 55 - 58.

\section{References}

1. Gosudarstvennoe upravlenie. Elementarnyi kurs. - M., 2002.

2. Kurakin A.V. Predmet administrativno-pravovogo regulirovaniya $v$ mekhanizme protivodeistviya korruptsii. Domodedovo, 2013. - S. 12.

3. Kurakin A.V., Kostennikov M.V. Aktual'nye problemy administrativnogo prava. - M., 2013.

4. Leont'ev M. Ideologiya suvereniteta // Odnako avgust-sentyabr' 2013 (169).

5. Natsional'naya ideya Rossii. T.

6. - M., 2012. 6. Rayanov F.M. Matritsa pravovogo gosudarstva i nasha yuridicheskaya nauka // Gosudarstvo i pravo. 2006. № 8.

7. Chirkin V.E. Konstitutsiya: rossiiskaya model'. - M., 2004.

8. Chirkin V.E. Gosudarstvovedenie. - M., 2012.

9. Kostennikov M.V. K voprosu o nekotorykh aktual'nykh problemakh administrativnogo prava // NB: Administrativnoe pravo i praktika administrirovaniya. - 2013. - 4. - C. 71 - 95. URL: http://www.e-notabene.ru/al/article_8840.html

10. Gulyaikhin V.N. Pravovoi mentalitet rossiiskikh grazhdan // NB: Voprosy prava i politiki. - 2012. - 4. - C. 108 - 133. DOI: 10.7256/2305-9699.2012.4.310. URL: http://www.e-notabene.ru/lr/article_310.html

11. Yu.A. Tikhomirov, G.A. Vasilevich Gosudarstvennoe upravlenie i perspektivy razvitiya // Zhurnal zarubezhnogo zakonodatel'stva i sravnitel'nogo pravovedeniya. - 2011. - 6. - C. 21 - 25.

12. N. M. Dobrynin Razmyshleniya o problemakh stanovleniya pravovogo gosudarstva v Rossii. // Pravo i politika. 2012. - 2. - C. 232 - 242.

13. Kupreev S.S. Tendentsii razvitiya gosudarstvennogo upravleniya v Rossii v 2008-2009 godakh // Administrativnoe i munitsipal'noe pravo. - 2010. - 2. - C. 55 - 58. 